- all budget for the new Framework programme should not be greater than that of its predecessor, the Fourth Framework, which started in 1994.

The main thrust of the British position is that Framework should be organized around "objective driven themes" that address the "medium-term technological needs of European industry" and the need to "improve the quality of life" - both important motifs in the 1993 white paper as well as support for European policies more broadly.

To achieve the first two goals, it suggests setting up a number of advisory groups, made up mainly of individuals representing user communities who, acting as 'proxy customers', would make recommendations on which the Commission would establish its strategic priorities.

A limited number of research and development programmes would then be identified as contributing to each of these priorities. These would then be aggregated to form "technology-specific delivery programmes", each allocated an agreed budget and monitored by what are described as "regulatory committees".

Britain suggests a number of possibilities for the strategic priorities, ranging from "sustainable farming and fishing" to "tomorrow's car". Six proposed programmes would contribute in varying degrees to the achieve-

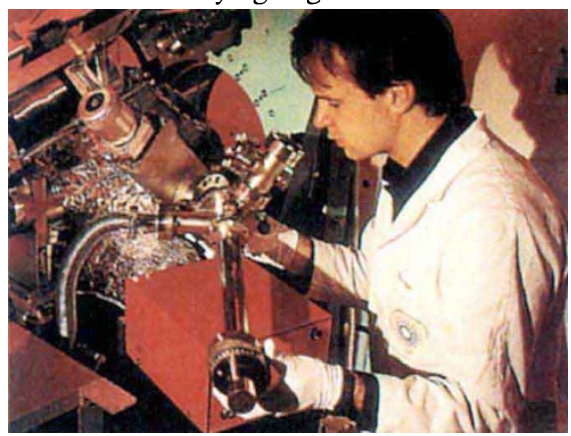

European synchrotron research: showing how collaboration can be effective.

ment of these goals, from information and communication technologies to life science and medical technologies.

Officials admit that this strategy has some similarities to the task force approach currently being pursued by the commission. But they claim it also has important differences. "Task forces are a bit too 'top-down', says Ian Taylor, Britain's minister for science. "They make a good starting point; but a task force that seems to anticipate [the outcome of a research programme] is not the most effective way of doing things."

At the same time, Taylor is cautious about Germany's suggestion of introducing a "variable geometry" for new programmes (see above left). "This is an untested idea. We would not close our eyes to it but would want to be convinced that it would have no budgetary implications, and want to see much more of what the idea would mean in practice."

A. A. \& D. D.

\title{
US bid to eliminate gene therapy panel under fire
}

Washington. Opposition is growing to a proposal by Harold Varmus, the director of the US National Institutes of Health (NIH), to disband the biomedical agency's Recombinant DNA Advisory Committee (RAC).

The 25-member panel of scientists, ethicists, lawyers and others is responsible for reviewing and approving novel genetherapy protocols. Varmus wants to hand over this function to the Food and Drug Administration (FDA), retaining at the NIH a committee that would convene conferences on novel gene-therapy topics.

But an official announcement of the proposal, due to have been published in the Federal Register several weeks ago, has been delayed, as opposition to the proposed dissolution of the committee has grown. Last week, for example, Lana Skirboll, associate director for science policy at the NIH, together with other NIH officials, briefed Senate aides at a meeting reported by one participant to have included "heated exchanges".

Individual senators who have voiced concern include David Pryor (Democrat, Arkansas), who is preparing a letter to Varmus for which he plans to gather the signatures of other members of the Senate and House of Representatives. "NIH should be trying to revise RAC, not abolish it," Pryor said in a statement, pointing out that the Congress relies on the panel for a "public dialogue" on issues raised by recombinant DNA and gene therapy.

Patient advocates also argue that the closed-door reviews conducted by the FDA - which is not charged with deciding the ethical merit of proposed experiments but only their safety and efficacy - are a poor substitute for public RAC meetings.

Skirboll says that the FDA takes ethical questions seriously, and would voluntarily refer to the NIH under the new system. This, she says, will be more forward-looking, anticipating controversial developments, such as the potential use of HIV as a vector, and convening conferences to outline recommendations well before protocols are developed.

One of those who approve the proposal is Inder Verma, a professor of molecular biology at the Salk Institute, in La Jolla, California, and chairman of a review committee that last year recommended that the RAC continue to approve protocols that raise new issues. He describes the proposal as "very sensible".

Verma says that a new standing advisory committee to NIH's Office of Recombinant DNA Activities (ORDA), proposed by Varmus, will "essentially be doing exactly the same thing" that the RAC now does, by holding public conferences on novel and controversial gene-therapy issues.

Meredith Wadman

\section{UK scheme aims to make biotech pay}

London. The British government this week unveiled a series of initiatives designed to boost the country's emerging biotechnology industry, and in particular to encourage more laboratory scientists to shake off their perceived inhibitions about entering the world of entrepreneurs.

The 'Crusade for Biotechnology', which spans several government departments, was launched in London by Ian Lang, President of the Board of Trade. It will provide scientists with management advice, business contacts and access to new money for ideas that can turn biotechnology research into commercial success.

Encouraged by a recent report from the accountancy firm Ernst and Young that places Britain at the top of Europe's biotechnology league table - the turnover of its bioscience companies was $£ 310$ million (US\$465 million) in 1995 , second only to the United States - the government is keen for the country to maintain this position. The figure accounts for one-third of biotechnology revenues in Europe.

"The race is only just beginning," said
Lang. "We cannot afford the luxury of selfcongratulation or, worse, the folly of complacency," he added.

The centrepiece of the new initiative is a $£ 25$-million fund providing access to capital for new biotechnology companies able to exploit technology developed at laboratories run by the Medical Research Council (MRC). The fund will last five years and be operated by a company owned by the MRC but governed by an independent board.

The initiative also includes $£ 7$ million for schemes offering advice to scientists on intellectual property rights, professional guidance on setting up pilot businesses known as 'incubators' - able to demonstrate the commercial potential of an idea, and three $£ 50,000$ prizes to encourage business ideas from young researchers.

Meanwhile, the Biotechnology and Biological Sciences Research Council is to collaborate with the Royal Society and the Engineering and Physical Sciences Research Council in a new scheme promoting contact between industry and university-based scientists.
Ehsan Masood 